\title{
第53回日本肺癌学会総会開催報告
}

\section{The 53rd annual meeting report of the Japan Lung Cancer Society}

\section{会長上岡博 (国立病院機構山口宇部医療センター)}

Hiroshi Ueoka (National Hospital Organization, Yamaguchi-Ube Medical Center)

それは2009年12月 7 日に受けた 1 本の電話から始ま りました。「XがんセンターのAです.上岡先生に次の 肺癌学会の副会長に立候補して頂きたいと考えてお電 話しました.是非扔願いします.」,「ちょっと待って下 さい. 肺癌学会の副会長という大役は, 地方の小さな 病院の院長にすぎない私には荷が重すぎます。私は力 不足ですので, 辞退させて下さい.」,「次は上岡先生に お願いしようということで, $\bigcirc \bigcirc \bigcirc$ 会メンバーの意 見は一致していますので, どうしても引き受けて頂き たいと思っています. 勿論, 正式には理事会での選挙 となりますが，私達が応援しますので大丈夫と思いま す.是非立候補して下さい.」,「そこまで言って下さる のでしたら，お引き受けしないといけないと思います が，私を次期副会長に推薦して頂くのは私個人を評価 して頂いたのではなく, 私が所属しております岡山大 学の肺癌グループがこれまでに行ってきた研究成果を 認めて頂いた結果だと考えますので, 私個人としてで はなく, 岡山の肺癌グループとしてお引き受けしたい と思います。それでよろしいでしょうか.」,「オーケー です.」以上のようなやりとりの結果, どうしても断 りすることが出来ず，立候補届けを提出することとな りました。その後はとんとん拍子に話しが進み, 2010 年 2 月19日の理事会で副会長候補に当選し, 2011年 2 月24日の理事会で会長候補となり, 11月 2 日の理事会, 評議員会, 総会で正式に会長として承認を受け, 第53 回日本肺癌学会総会を担当することが決まりました。

その後の準備としては,まず期日を2012年11月 8 日， 9 日の 2 日間, 場所は岡山肺癌治療研究会の事務局が ある岡山市とし, 岡山コンベンションセンター, ホテ ルグランヴィア岡山, 岡山市デジタルミュージアム, 岡山全日空ホテルの 4 会場で行うことにしました. 学 会のプログラム作成にあたる企画委員会の委員長を岡

\section{平成 24 年 12 月受理}

₹755-0241 山口県宇部市東岐波685

電話：0836-58-2300 FAX : 0836-58-5219

E-mail : ueokah@yamaguchi.hosp.go.jp
山大学病院呼吸器・アレルギー内科の木浦勝行教授に お願いし，学会事務局は山口宇部医療センターに置い て，事務局長は山口宇部医療センターの杉和郎前副院 長（2011年 9 月に松本常男現副院長に変更）としまし た. 2011年 9 月には理事, 評議員の先生方にプログラ ムに関するアンケートを行い, その結果を参考にして, 13名の委員（岡山大学からは木浦教授以外に腫瘍セン 夕一田端雅弘准教授, 呼吸器外科 豊岡伸一先生, 呼 吸器内科 堀田勝幸先生) からなる企画委員会を 11 月 4 日，2012年 1 月 14 日，3 月 24 日の計 3 回開催し，プロ グラムの大枠を決めました.学会のメインテーマは「肺 癌の克服に向けて一現状の解析と将来への提言一」 としました (写真 1 ). 演題登録は 4 月 4 日から 5 月 31 日までに行いましたが, シンポジウムなどの指定演題 を除く純粋の公募演題として過去最高の 1,197 題が登 録されました９5名の査読委員による厳格な査読の結 果, 採択された演題は会長講演 1 題, 特別講演 1 題, シンポジウム 27 題, ワークショップ 96 題, プレナリー セッション 4 題, 教育講演 16 題, 肺癌登録合同委員会 報告 1 題, 篠井・河合賞受賞講演 2 題, ビデオセッシ ヨン 47 題, 一般口演 550 題, ポスター 505 題に加えて, 外国人招待者による Invited Lecture 3 題, 世界肺癌学

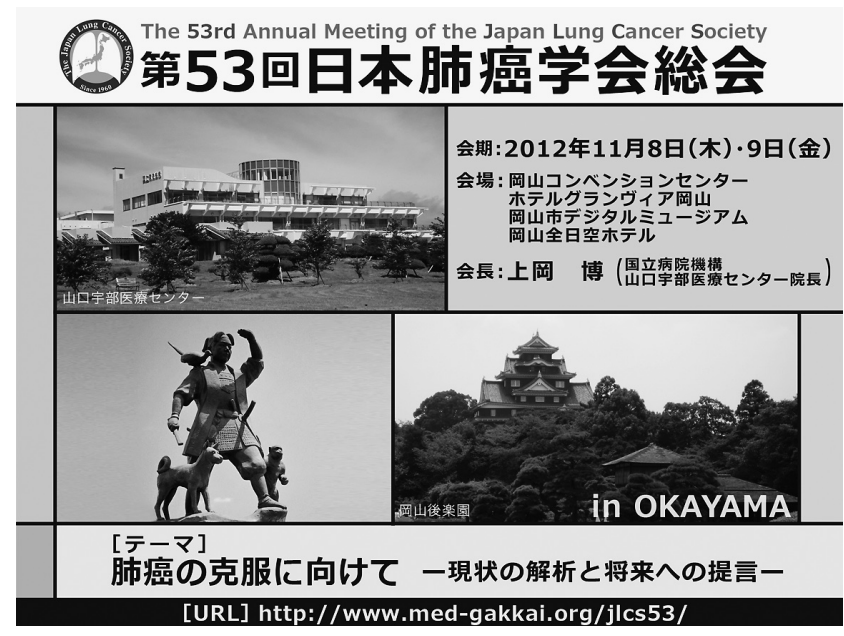

写真 1 第53回日本肺癌学会総会のポスター 
会（IASLC）との Joint Symposium 6 題, 韓国肺癌学 会 (KASLC) との Joint Symposium 4 題, Clinical Science Symposium 3 題, Young Investigators Symposium 3 題の計1,269題でした.

11月 7 日（水）からいよいよ本番となり, 午前中に 30の各種委員会が開催され, 午後には理事会, 評議員 会が行われました。そして夜にはホテルグランヴィア 岡山で, 240 名にご出席頂き評議員懇親会を盛大に開催 しました。私の開会挨拶と中西洋一日本肺癌学会理事 長のご挨拶に続いて，いずれも私の恩師である愛知県 がんセンター名誉総長の小川一誠先生, 近畿大学名誉 教授の福岡正博先生, 岡山大学医歯薬学総合研究科長 の谷本光音先生 (写真 2 a ) にご祝辞を頂き, 岡山大 学前教授 (九州大学前教授) の原田実根先生（写真 2 b ）による乾杯にて賑やかな懇親会が行われました。 岡山大学からも名誉教授の平木祥夫先生, 清水信義先

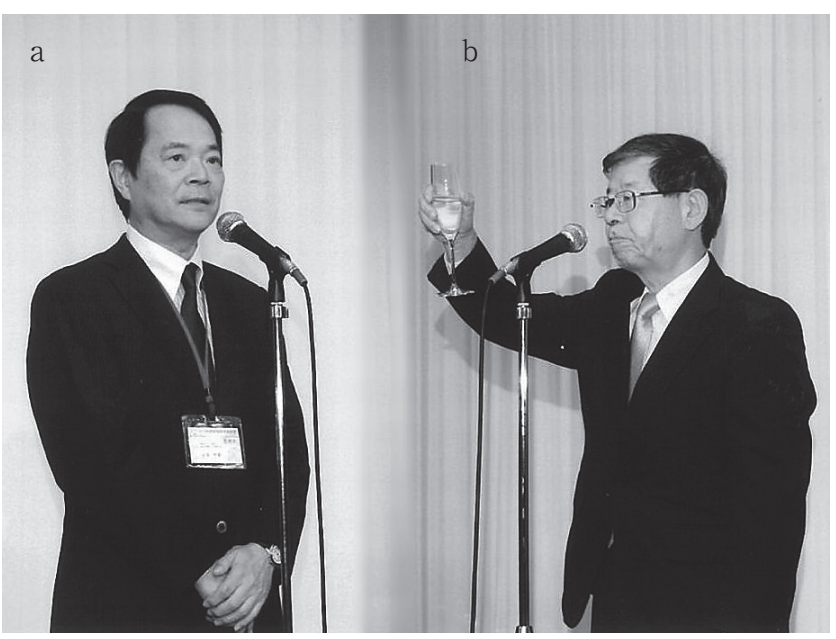

写真 $2 \mathrm{a}$. 谷本光音先生のご祝辞, b . 原田実根先生の乾杯 のご発声

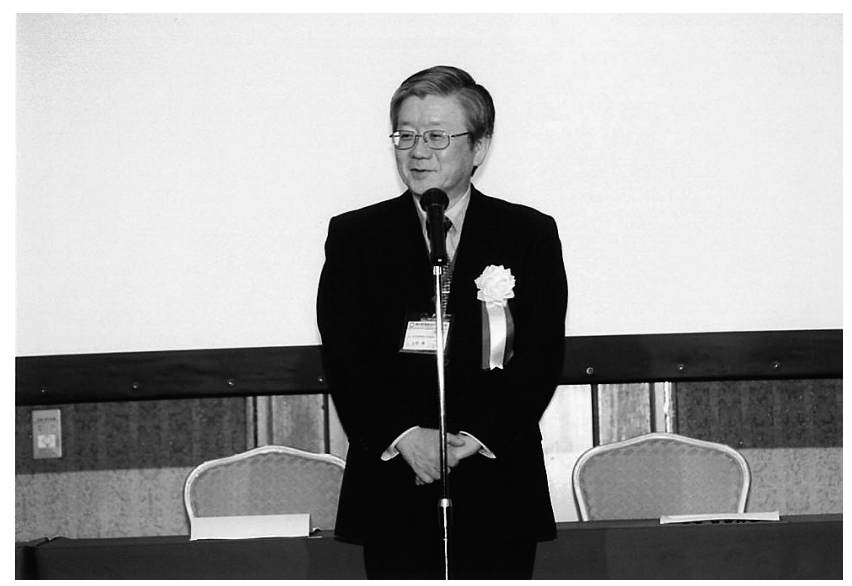

写真 3 上岡 博による開会の挨拶
生，中田安成先生，および片岡幹男教授をはじめとす る多数の教官にご参加いただきました。また，名誉会 員, 特別会員の先生も多数ご参加下さいましたので, 旧交を温めて頂くとともに，岡山の夜を楽しんで頂け たと思います。

11月 8 日（木）は，朝 8 時 40 分に第 1 会場に掞ける 私の開会挨拶（写真 3 ）で学会第 1 日目が始まりまし た。第 1 会場では, 最初に「肺癌の克服に向けて—現 状の解析一」という本学会のメインテーマに基づく前 半のシンポジウムを行いましたが，学会の先陣を飾る に相応しい活発な討議が行われました。続いて福島県 立医科大学副学長の山下俊一先生による「福島原発事 故と放射線健康リスク管理」という東日本大震災を教 訓とした特別講演が行われました。午後には, 私が「肺 癌診療における岡山グループの役割—過去, 現在, 未 来一」というタイトルで会長講演を行い, 木村郁郎名 誉教授と大慰泰亮先生が立ち上げられた岡山大学第二 内科を中心とする岡山肺癌グループの業績を創設期か ら, 体制確立期, 発展期の 3 期に分けて解説し, 今後 目指すべき方向などを括話しさせて頂きました。続い てプレナリーセッションにおいては, 査読委員会が選 んだ最優秀の 4 演題が報告され, 1,200名を収容できる 会場を埋め尽くす多数の聴衆の中，メインテーマであ る肺癌の克服に向けて喧々諤々の議論が行われました

(写真 4 )。また，「肺癌診療における国際協力」のシ ンポジウムでは, グローバル時代において日本肺癌学 会の果たすべき役割に関して討議されました。今回第 8 会場では, 肺癌学会で初めての試みとして, 海外に 留学中の若手研究者 3 名に, 海外での研究生活, 研究 成果を報告して頂くYoung Investigators Symposium

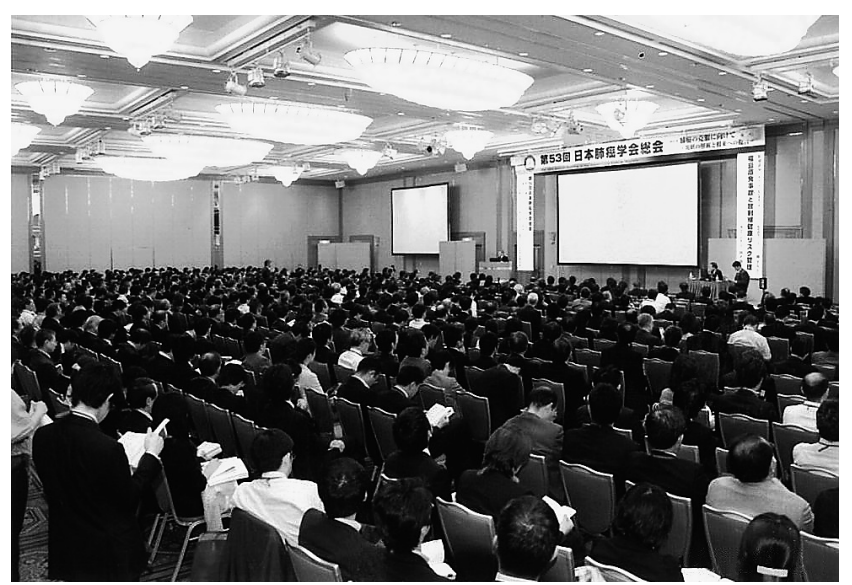

写真 4 プレナリーセッションの会場 
を行いましたが, 国内で頑張っている若手研究者にと って有意義なセッションになったと考えています。夜 には, 岡山全日空ホテルで会員懇親会を行い, 約300名 の会員にご出席頂きました。お酒が全く飲めない木浦 勝行教授の乾杯 (写真 5 ) で始まり, 約 2 時間楽しい 会が続きました。会員の親睦が大いに深まったと思い ます。

11月 9 日（金）は, 第 1 会場では, 「進行肺癌化学療 法の最前線」,「分子標的治療の最前線」という二つの シンポジウムが行われましたが, いずれも大変好評で, 活発な討議が行われました。また, 岡山大学呼吸器外 科の豊岡伸一先生が「胸部悪性腫瘍における分子生物 学的異常の解明と治療への応用」というタイトルで篠 井・河合賞受賞講演をされました。午後には,「肺癌の 克服に向けて一将来への提言一」という学会メイン テーマの後半部分であり, 本学会の総仕上げとなるシ ンポジウムが行われましたが, 最後まで熱心な討議を して頂き, 肺癌診療の進歩につながる素晴らしい議論 が出来たと考えております。

第 2 会場では，2 日間を通じて，外国人講演者によ る Invited Lecture, IASLC との Joint Symposium, KASLC との Joint Symposium, Clinical Science Symposium など, 英語での発表が行われました. 残念 ながら会場は満席にはなりませんでしたが, 世界に発 信できる素晴らしいディスカッションが出来たようで す。また，本学会では肺癌の診断，治療から緩和医療， 予防に至る多くのテーマに関して17のワークショップ が行われましたが, 特に「EGFR 遺伝子変異陽性肺癌 に対する治療戦略」,「ALK 融合遺伝子陽性肺癌に対す る治療戦略」という最近注目されているテーマを取り

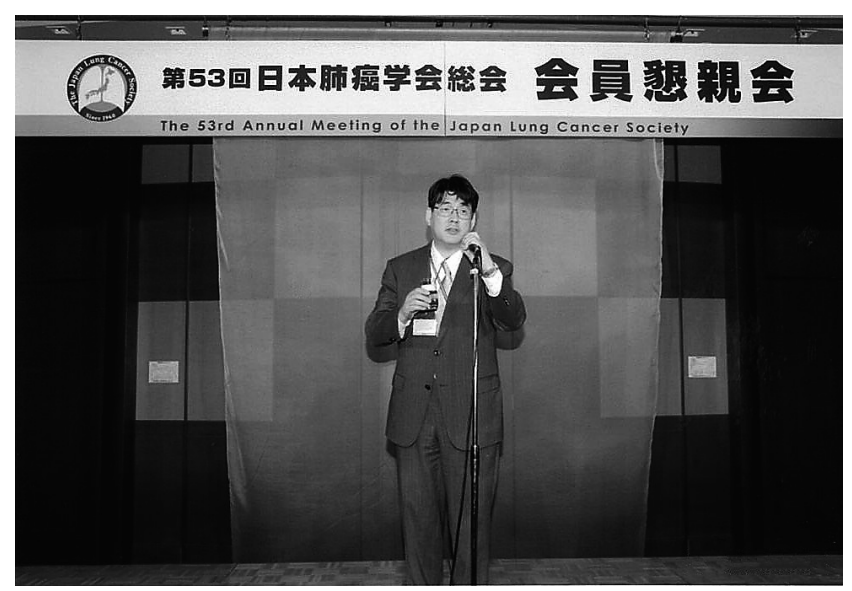

写真 5 木浦勝行先生の乾杯のご発声
上げたワークショップでは，会場に入れない人が出る ほど盛り上がりました。ささらに，第 6 会場では，2 日 間で16の教育講演が行われましたが,700席の会場は常 時ほとんど満席状態で, 若い研究者の知識向上に寄与 できたのではないでしょうか. 岡山市デジタルミュー ジアムでは，ポスター発表が行われましたが，発表時 間には通路を歩けないほど多くの聴衆が集まり，活気 にあふれた討論が行われていました。

全ての演題が終了した後，18時10分から第 1 会場で 閉会式を行いました。最初に中西理事長より私に日本 肺癌学会の感謝状が授与されました. 前もって知らさ れていなかったため，大変驚きましたが，じっくりと うれしさがこみ上げてきました。その後最後まで参加 して下さった皆様に私から感謝の言葉を述べさせて頂 き, 来年東京で開催される第54回日本肺癌学会総会で の再会を約束して閉会とさせて頂きました。

本学会の参加者数は, 米国本土を襲ったハリケーン の影響と急な病気のため 2 名の外国人が来日できませ んでしたが, 外国人招待者 12 名を含め, 総数 3,128 名と なり，これまでで最高の人数になりました。岡山市と いう地方での開催にもかかわらず，このように多数の 皆様にご参加頂きましたことを主催者として大変感謝 するとともに，誇りに思っております。

11月10日（土）には, 岡山県健康づくり財団附属病 院長の西井研治先生のお世話で，第27回肺がん集検セ ミナーが岡山コンベンションセンターで開催されまし た. 参加者は100名で，「死亡率減少に寄与する肺癌検 診を目指して」というテーマのもと, 既存の肺癌検診 制度の効率化と精度管理の向上，胸部 CT 検診の被曝 線量管理などが討議されました。また，同じくコンベ ンションセンターにおいて，「肺がんをなおす」という タイトルで市民公開講座を開催しました。京都大学呼 吸器外科教授の伊達洋至先生に外科医の立場から, 岡 山大学呼吸器・アレルギー内科教授の木浦勝行先生に 内科医の立場から肺癌の撲滅に向けた最新の試みをわ かりやすくご講演頂きました. 230 名の方にご参加頂 き, 講演後には有意義な討議が行われました。

最後になりますが，浅学非才の私がこの学会を成功 裡に終えることが出来ましたのは，企画委員長を扮努 め頂いた木浦勝行教授，会長講演の司会をして頂いた 谷本光音教授をはじめとする岡山大学第二内科の皆 様，企画委員として外国人の招請にご尽力頂いた岡山 大学第二外科の豊岡伸一先生と三好新一郎教授, 事務 
局にて諸事万端を見事にこなして頂いた松本常男副院 長をはじめとする山口宇部医療センターの皆様, およ び岡山肺癌治療研究会の皆様の全面的なご協力の賜と 思っています (写真 6 ). 学会会期中は素晴らしいお天 気に恵まれました。「晴れの国岡山」で開催して良かっ たと思うとともに，岡山大学医学部の底力を実感した 4 日間でした。ご協力頂きました全ての皆様，本当に 有り難うございました。

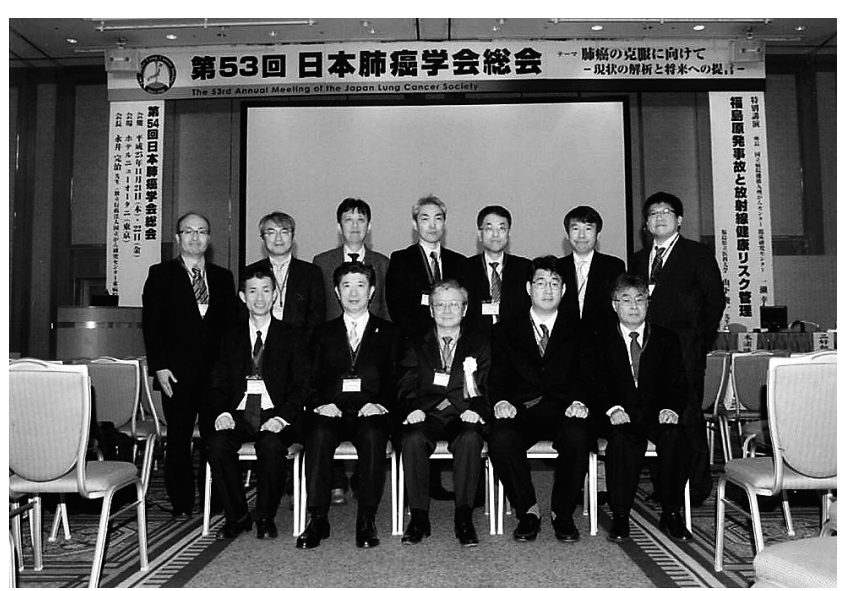

写真 6 学会を支えて頂いたメンバー：前列中央が上岡 博, 右となりが木浦勝行先生, 左となりが日本肺癌学会理事 長中西洋一先生 